\title{
Effect of crude oil pollution on heavy metal contents, microbial population in soil, and maize and cowpea growth
}

\author{
Gabriel Olulakin Adesina*, Kasali Amofe Adelasoye \\ Department of Crop and Environmental Protection, Faculty of Agricultural Sciences, Ladoke Akintola University of Technology, \\ Ogbomoso, Nigeria; ${ }^{*}$ Corresponding Author: olulakinadesina@gmail.com, goadesina@lautech.edu.ng, \\ amofelade@yahoo.com
}

Received 12 November 2013; revised 13 December 2013; accepted 24 December 2013

Copyright (C 2014 Gabriel Olulakin Adesina, Kasali Amofe Adelasoye. This is an open access article distributed under the Creative Commons Attribution License, which permits unrestricted use, distribution, and reproduction in any medium, provided the original work is properly cited. In accordance of the Creative Commons Attribution License all Copyrights (C) 2014 are reserved for SCIRP and the owner of the intellectual property Gabriel Olulakin Adesina, Kasali Amofe Adelasoye. All Copyright (C) 2014 are guarded by law and by SCIRP as a guardian.

\section{ABSTRACT}

The effect of crude oil pollution on heavy metal content in the soil, microbial population, and growth performance of maize and cowpea was investigated. The heavy metals determined were lead, cadmium, iron, nickel, zinc and copper. Microbial population and growth performance of maize and cowpea in both polluted and unpolluted soils samples were evaluated. Results showed that higher concentration of heavy metals was observed in all crops planted in polluted soil, polluted site vegetation and soils. The total heterotrophic bacteria was $89 \%$ lower in the polluted soil than in the unpolluted soil while fungi was $78 \%$ lower in the polluted soil when compared to the unpolluted soil. However, hydrocarbon utilizing bacteria and fungi was $22 \%$ and $24 \%$ higher in the polluted soil than in the unpolluted soil respectively. Maize and Cowpea performed poorly in polluted soil when compared with unpolluted soil as evidenced in the growth parameters measured for both crops.

\section{KEYWORDS}

Pollution; Heavy Metals; Microbial Population

\section{INTRODUCTION}

Crude oil occurs naturally as a complex mixture of hydrocarbon and non-hydrocarbon compounds which contains a measurable toxicity towards living organisms at concentration [1]. The demand for crude oil as a source of energy and primary raw material for industries has increased. This has led to an increase in production, transportation and refinery which have therefore resulted in grossing pollution of the environment [2]. The major contributor to this environmental pollution is oil spillage. Oil spillage refers to the accidental leakage of crude oil or refined products on land or water during the process of transportation or distribution resulting in environmental pollution. The incidence of oil spillage occurs in different parts of the world causing serious problems and hazards to the environment. Nigeria is a major exporter of crude oil and the nation has therefore experienced several oil spills which affected agricultural lands as well as plants growth and development in the areas affected. [3]. The Nigerian National Petroleum Coporation (NNPC) in 1986 reported a total of about 5000 barrels of crude oil spillage from Nigerian Agip Oil Company (NAOC) pipeline near Oshika in Rivers State in August, 1983 [4]. Nwanko, [5] reported about 2000 oil spillages in Nigeria between 1976 and 1988. During this period about 212 barrels of crude oil were discharged into the environment. Furthermore, the Department of Petroleum Resources 1991 [6] recorded total oil spill incidence of 2796 between the periods of 1975-1990. This was caused by the oil companies in the terrestrial, costal and offshore marine environment while Nigeria Agip Oil Company (NAOC) in 1996, observed a total of 86 incidence of oil spill cases. Several studies on oil spills and environment in the Niger Delta area and other tropical areas throughout the world consistently showed that areas that are directly exposed to large or repeated oil spills or leaks frequently exhibit long-term environmental problems [7,8].

Several authors have reported the detrimental effects 
of oil spillage to soil which has hampered agricultural activities and also adversely affected soil dependant organisms [2,9]. Heavy metals are often used as a group name for metals and semimetals (metalloids) that have been associated with contamination and potential toxicity or ecotoxicity [10]. The general increase of heavy metal content in the soil has been largely caused by crude oil spillage [11]. Heavy metal pollution of the soil is caused by various metals especially copper, Nickel, Cadmium, Zinc, Chromium, and lead [12]. It has been observed that the pollution caused by heavy metal does not only results in adverse effects on various parameters relating to plant quality and yield but also causes changes in the size, composition and activity of the microbial activities [13].

Soil microbes are groups of microorganisms for which the soil is the natural habitat. Soil microorganisms consist of both prokaryotes (bacteria, actino-mycetes, bluegreen algae) and eukaryotes (fungi, microscopic algae, protozoans). The diversity and activity of soil microbes play a vital role in recycling of plant nutrients, maintenance of soil structure and detoxification of noxious chemicals [14]. Crude oil spillage is one of the factors that affect soil microflora activities in the soil. A decrease in bacterial species richness and a relative increase in soil actinomycetes or even decreases in both the biomass and diversity of the bacterial communities in contaminated soils are caused by presence of heavy metals. The need to investigate activities of soil microorganisms in ecosystems that have been exposed to long-term contamination by heavy metals has been suggested [14].

Maize is a cereal crop cultivated for food, feed and industrial purposes [15]. It is one of the main staple cereals in Nigeria [16]. Maize is an important source of carbohydrate in human food. A useful quality of Vitamins $\mathrm{C}$ can be derived from maize while the yellow grain contains vitamin A [17]. Industrially, maize is used as livestock feeds and also serves as raw material for starch, flour and alcohol production [16,17]. Cowpea (Vigna unguiculata L. Walp.) is an annual grain legume and it is a main source of dietary protein which complements staple low-protein cereal and tuber crops [18,19]. Cowpea can be used to control erosion and restore fertility in poor soil. It is also used as a cover crop to suppress weeds [20]. Hay obtained from cowpea plays a particularly vital role in feeding animals during the dry season [21,22].

Plants root can absorb heavy metals in the soil most especially where there is contamination [23]. When these heavy metals are taken up by plant roots, it results in chlorosis, weak plant growth, yield reduction, reduced nutrient uptake, disorders in plant metabolism and reduced ability to fix molecular nitrogen in leguminous plants [24]. The uptake of these heavy metals by plants and accumulation in the food chain is a serious threat to both animal and human health [25].

The presence of heavy metals in human body is toxic and they accumulate in the soft tissues. High level ingestion of toxic metals has undesirable effect on humans which becomes obvious only after several years of exposure to it [26].

The objectives of this study were to determine the effects of crude oil pollution on soil heavy metal contents, microbial population, and on the growth performance of maize and cowpea.

\section{MATERIALS AND METHODS}

The study was conducted at Ladoke Akintola University of Technology, Ogbomoso, Nigeria, (latitude $08^{\circ} 10^{\prime} \mathrm{N}$ and longitude $\left.04^{\circ} \mathrm{E}^{\prime}\right)$ in 2011. Surface (0 - $15 \mathrm{~cm}$ depth) soil samples from crude oil polluted sites and unpolluted sites were collected from five different points with the aid of bucket auger along PPMC Warri-Kaduna crude oil pipeline spill site near Effurun Round about Warri, Delta state. The soil samples were mixed thoroughly, air dried and sieved with $2 \mathrm{~mm}$ mesh sized sieve to remove debris. $2 \mathrm{~kg}$ each of polluted and unpolluted soil samples were weighed and transferred into each of the planting pots.

Samples of natural vegetations found at the polluted site and from adjacent unpolluted site were collected. The plant samples were oven dried at $65^{\circ} \mathrm{C}$ for $72 \mathrm{hrs}$, ground and taken to the Laboratory for determination of heavy metals.

Three seeds each of maize or cowpea were planted into each of the pots. There were three replicates of each soil type and test crop laid out in completely randomized design. The seedlings were thinned to one per pot at one week after planting (WAP. Watering was done as necessary. The seedlings were allowed to grow for 6 weeks. Growth parameters assessed on maize and cowpea plants were plant height and number of leaves produced. The shoots of the test crops were cut at ground level with a sharp knife put in well labeled envelopes and dried in the oven at $75^{\circ} \mathrm{C}$ for $72 \mathrm{hrs}$ for dry matter determination. The dried samples were milled and taken to the laboratory for phyto-extraction and measurement of heavy metals in their tissues. Vegetations samples that were collected from the polluted and unpolluted sites were also treated as above. No fertilizer or pesticide was applied throughout the whole of experimental period. All samples analysed for heavy metals were digested and were then read from an Atomic Absorption Spectrophotometer (AAS) Milton Roy 2ID using their respective lamp and wavelengths. Calculation was done using:

Meter Reading X Slope X Dilution factor [27].

In estimating microbial population, standard methods were used to prepare nutrient agar (NA) and potato dextrose agar (PDA) for estimation of microbial population. One gramme each of the soil samples were measured 
into the test tube containing $9 \mathrm{ml}$ sterile distilled water and serially diluted to dilution factor $\left(10^{-5}\right)$ and $1 \mathrm{ml}$ of the last dilutions was pipette into sterile plate which were incubated at $28^{\circ} \mathrm{C}-30^{\circ} \mathrm{C}$. All plated were incubated inverted wise. Microbial counted were done at 48 hours for NA and 72 hours for PDA in the Petri plates. Data collected were subjected to analysis of variance and treatment means compared using t-test.

\section{RESULTS}

\section{Effects of Crude Oil Pollution on Heavy Metal Content of the Soil}

The result of chemical analysis carried out on soils and plants of the environment where oil pollution was observed is shown in Table 1. The details of trends of the heavy metal concentration in both the polluted, unpolluted, crops (maize and cowpea), and natural vegetation growing on these soils were shown in Figures 1(a)-(g). Generally, higher concentration of heavy metals was observed in all polluted crops, site vegetation and soils. Among all the heavy metals detected in the soil, highest concentration of Lead was observed in polluted maize (35.5 ppm) while the lowest concentration of Lead was observed in unpolluted Cowpea (4.8 ppm). This is a strong indication that maize is a good hyper-extractor which can be used in the process of phyto-remediation of crude oil polluted site. The $\mathrm{Pb}$ concentration in polluted site vegetation was $43 \%$ higher than the concentration in unpolluted site vegetation. The same trend was observed in soil samples where lead $(\mathrm{Pb})$ concentration in polluted site soil was $44 \%$ (5.7 $\mathrm{ppm}$ ) higher than unpolluted site soil (0.3 ppm) (Figure 1(a)). Figure $1(\mathbf{b})$ shows the concentration of Cadmium in all the tested plant and soil. Highest concentration was observed in polluted maize (9.1 ppm) while the lowest concentration was observed in unpolluted cowpea (3.0 ppm). Similar trends was observed in polluted site soil and vegetation samples from the location of oil pollution and this is clearly shown in Figure 1(b).

Higher concentration of Fe was observed in polluted maize (1041 ppm) as compared to unpolluted maize (647 ppm). Similar trend was observed in cowpea. Higher concentration of Iron was also observed in polluted site vegetation (744 ppm) when compared with unpolluted site vegetation (417 ppm) and the same trend for polluted and unpolluted soil samples with 1553 and 807 ppm concentrations respectively (Figure 1(c)),

Figure 1(d) shows the concentration of chromium on polluted soil sowed with maize and cowpea. Highest concentration of Chromium was observed in polluted Cowpea (33 ppm) while the lowest concentration of Chromium was observed in unpolluted maize (7.2 ppm). This confirms that cowpea has ability to extract and accumulate chromium than maize. Higher concentration of Chromium was also observed in polluted site vegetations (16.8 ppm) while unpolluted site vegetation has lower concentration $(8.3 \mathrm{ppm})$. Also, high concentration of Chromium was observed in polluted site soil (11.7 ppm), while lower concentration of Chromium was observed in

Table 1. Concentrations of heavy metals in different plants of polluted and unpolluted environment.

\begin{tabular}{|c|c|c|c|c|c|c|c|}
\hline \multirow{2}{*}{ Treatments } & \multicolumn{3}{|c|}{$\longleftarrow$} & \multicolumn{4}{|c|}{ Heavy Metals (ppm) } \\
\hline & (Lead) Pb & Cadmium (Cd) & Iron $(\mathbf{F e})$ & Cromium (Cr) & Nickel (Ni) & Zinc (Zn) & Copper (Cu) \\
\hline PC & $8.40 \mathrm{a}$ & 6.68a & 1423.31a & $32.90 \mathrm{a}$ & 39.19a & $560.35 a$ & $15.38 \mathrm{a}$ \\
\hline UC & $5.02 b$ & $3.12 b$ & $953.47 \mathrm{~b}$ & $22.70 \mathrm{~b}$ & $22.80 \mathrm{~b}$ & $103.71 b$ & $8.16 b$ \\
\hline LSD & 2.36 & 1.41 & 100.5 & 3.92 & 3.97 & 89.73 & 2.71 \\
\hline PM & $35.51 \mathrm{a}$ & $9.05 a$ & 1041.0a & $29.90 \mathrm{a}$ & 39.19a & 651.10a & $9.24 a$ \\
\hline UM & $5.96 b$ & $4.10 \mathrm{~b}$ & $647.20 \mathrm{~b}$ & $7.17 \mathrm{~b}$ & $35.50 \mathrm{~b}$ & $280.82 b$ & $4.93 \mathrm{~b}$ \\
\hline LSD & 4.63 & 2.19 & 26.38 & 4.45 & 1.67 & 33.94 & 1.53 \\
\hline PSV & $17.28 \mathrm{a}$ & 3.30a & 744.48a & $16.76 a$ & $21.71 \mathrm{a}$ & 553.84a & $11.89 a$ \\
\hline USV & $7.39 b$ & $2.40 \mathrm{~b}$ & $417.18 \mathrm{~b}$ & $8.31 b$ & $14.31 \mathrm{~b}$ & $220.09 b$ & $4.66 \mathrm{~b}$ \\
\hline LSD & 2.31 & 1,15 & 123.97 & 2.14 & 2.38 & 8.07 & 1.21 \\
\hline PSL & $5.68 \mathrm{a}$ & $4.80 \mathrm{a}$ & 1553.91a & $11.68 \mathrm{a}$ & $24.34 a$ & 223.09a & $18.96 a$ \\
\hline USL & $0.25 b$ & $1.86 \mathrm{~b}$ & 807.10b & $4.15 b$ & $9.81 \mathrm{~b}$ & $106.34 \mathrm{~b}$ & $8.46 \mathrm{~b}$ \\
\hline LSD & 1.40 & 0.69 & 23.99 & 1.11 & 2.26 & 9.69 & 5.76 \\
\hline
\end{tabular}

PM = Polluted Maize, UM = Unpolluted Maize, PC = Polluted Cowpea, UC = Unpolluted Cowpea, PSV = Polluted Site Vegetation, USV = Unpolluted Site Vegetation, PSL = Polluted site Soil, USL = Unpolluted site Soil. ${ }^{\dagger}$ Means followed by a common letter within the same column do not differ significantly at 0.05 probability level. 


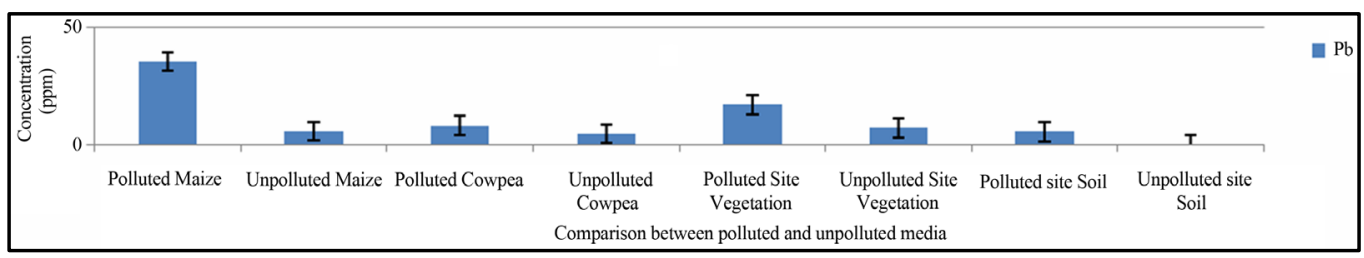

(a)

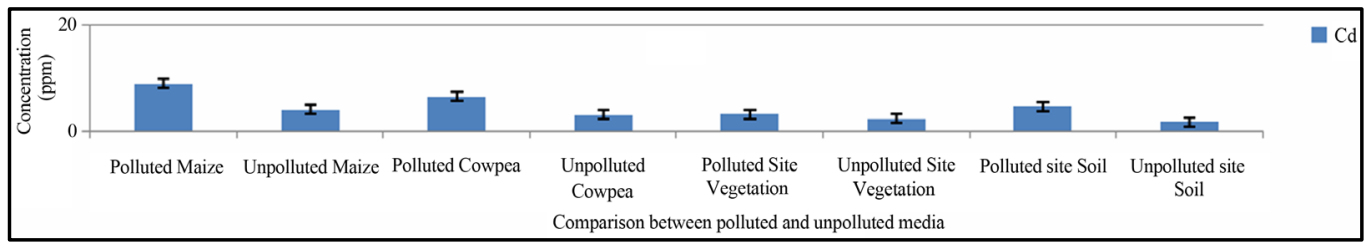

(b)

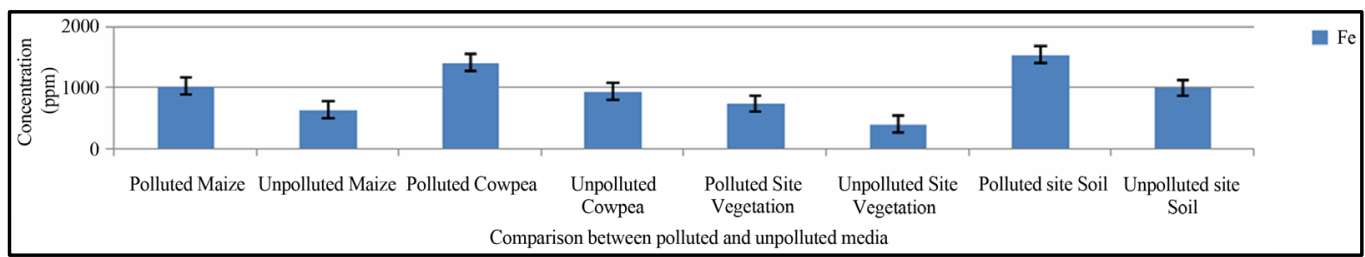

(c)

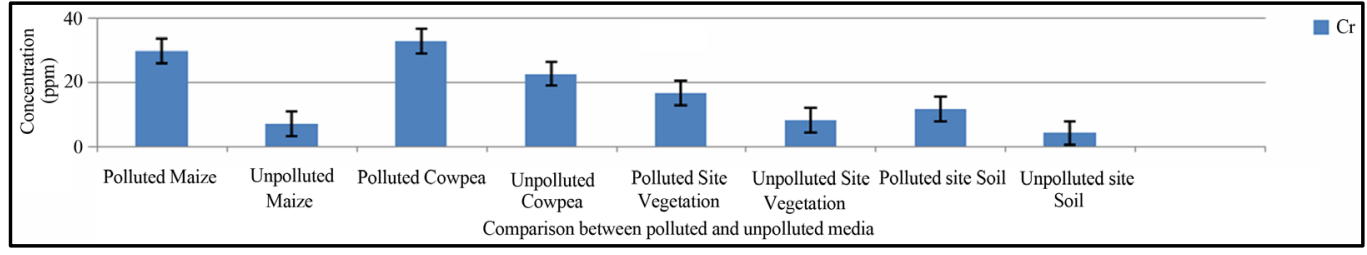

(d)

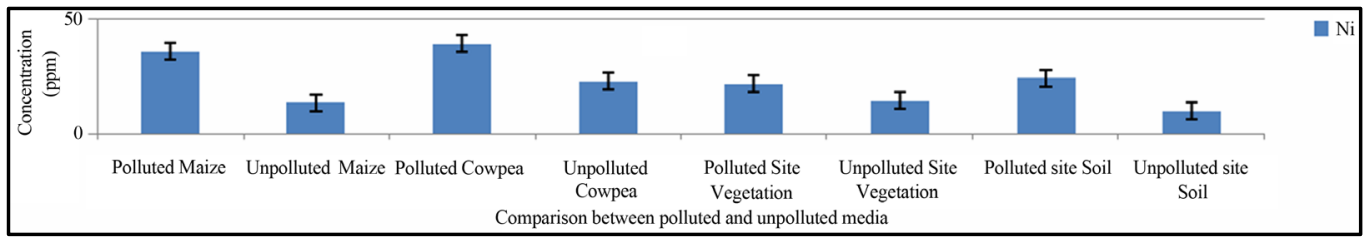

(e)

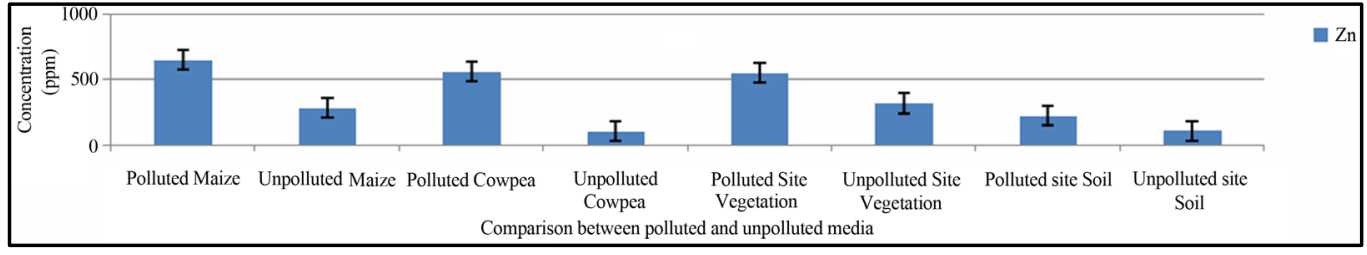

(f)

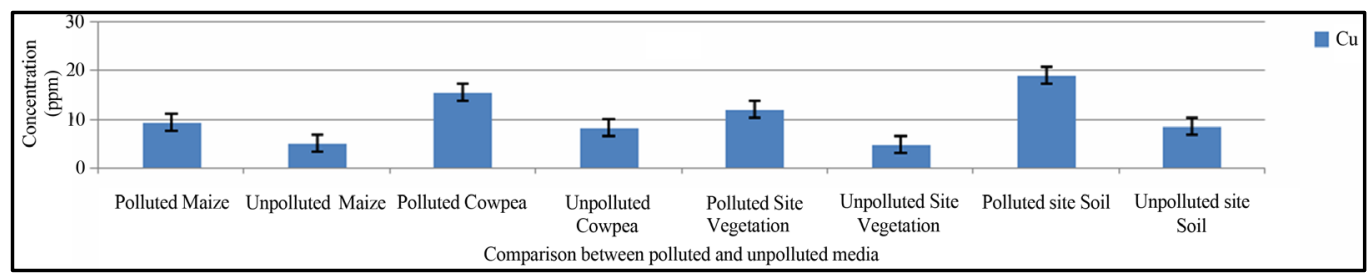

(g)

Figure 1. (a)-(g): Effects of crude oil pollution on the concentration of heavy metals in soil and different plants of polluted and unpolluted environment. 
unpolluted site soil (4.2 ppm).

In Figure 1(e), higher concentration of Nickel was observed in polluted maize (36 ppm) while the lower concentration of Nickel was observed in unpolluted maize (13.5 ppm). Similarly highest concentration of Nickel was observed in polluted cowpea (39.2 ppm) while lower concentration of Nickel was observed in unpolluted cowpea (22.7 ppm). The same trend observed observed in polluted site vegetation (21.7 ppm) when compared with unpolluted site vegetation (14.3 ppm). Polluted site soil sample Nickel concentration is (24.3 ppm), while lower concentration of Nickel was observed in unpolluted site soil (9.8 ppm).

However, higher concentrations of these heavy metals imposed by the crude oil pollution have negative effects on the vegetations. In Figure 1(f), highest concentration of Zinc was observed in polluted maize (651 ppm) while the lower concentration was observed in unpolluted maize (280 ppm). Similarly, trend was observed for cowpea, soil samples and vegetations from sampling sites. In Figure 1(g), higher concentration of Copper was observed in polluted maize (9.243 ppm), polluted cowpea (15.383 ppm), polluted site vegetation (11.896 ppm) and polluted site soil (18.961 ppm). Reverse was the case for unpolluted samples.

In Plates 1(a) and (b), it was evident that good growth was observed in maize grown on unpolluted soil due to favorable conditions while poor growth and etiolating of leaves was observed on maize grown on crude oil polluted soil. This was as a result of unfavorable soil condition due to crude oil pollution which has resulted in poor aeration of the soil, depletion of soil nutrients and inhibition of enzymatic and soil microbial activities that emanated from the pollution. On cowpea plant (Plate 1(b)), above observation was true as the growth of plant in polluted soil reveals environment not suitable for plant growth as revealed in the picture.

In Table 2, the number of leaves and crop height in maize were noticed to be greater in the unpolluted site soil than polluted site soil. The number of leaf in polluted maize was lower (2) while the number of unpolluted maize was (5). Similarly, the height of polluted maize was $(12 \mathrm{~cm})$ while the height of unpolluted maize was $(23 \mathrm{~cm})$. The same trend was observed in cowpea sown on polluted and unpolluted soil. Height of cowpea plant was observed to be greater in the unpolluted site soil than polluted site soil so also is the number of leaf in polluted cowpea was lower (3) than the one sowned in unpolluted soil (5). The height of cowpea in the fourth week was $77 \%$ higher in the unpolluted site soil than the polluted site soil.

In Figure 2, microbial analysis of the crude oil polluted and unpolluted soil reveals that higher population

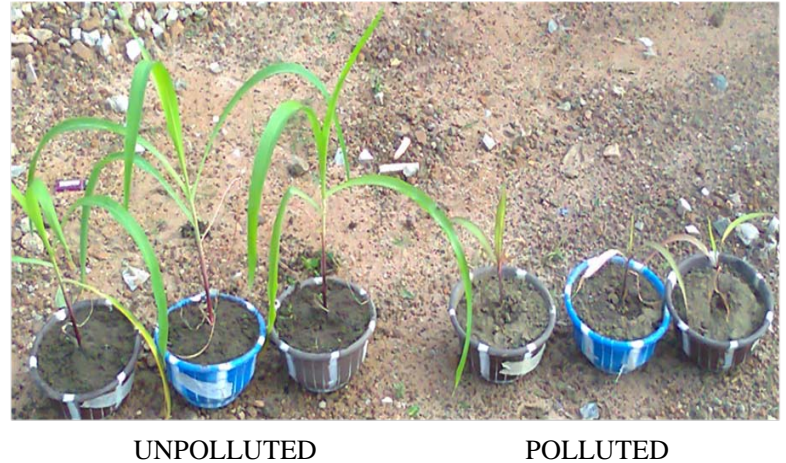

(a)

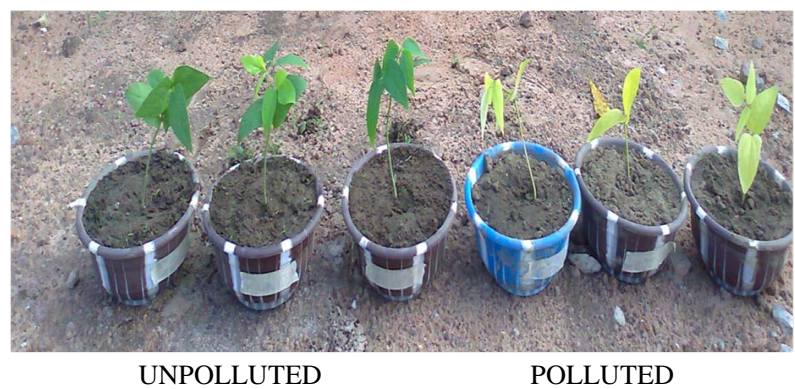

(b)

Plate 1. (a) and (b): Effects of crude oil pollution on growth performance of maize and cowpea at the screen house Ladoke Akintola University of Technology, Ogbomoso. (a) Maize Crop; (b) Cowpea Crop.

of HUB (Hydrocarbon utilizing bacteria) was recorded in the crude oil polluted soil $\left(9.4 \mathrm{cfu} / \mathrm{g} \times 10^{3}\right)$ than unpolluted soil $\left(1.1 \mathrm{cfu} / \mathrm{g} \times 10^{3}\right)$. Similarly, higher population of HUF (Hydrocarbon utilizing fungi) was recorded in crude oil polluted soil $\left(3.8 \mathrm{cfu} / \mathrm{g} \times 10^{3}\right)$ than unpolluted soil. This is as a result of the presence of hydrocarbon which serves as source of food for the HUB and HUF. This has favored the rapid replication of HUB and HUF thereby resulting to high population in crude oil polluted soil. The lower microbial population of HUB and HUF observed in unpolluted soil was as a result of unfavorable condition imposed by lack of food.

Inversely, it was also observed that the microbial population of Total Heterotrophic Bacteria (THB) and Total Fungi (TF) are lower in crude oil polluted soil. This is as a result of adverse effect of the crude oil on the microbial population. The total heterotrophic bacteria was $89 \%$ lower in the polluted soil than in the unpolluted soil while total fungi was $78 \%$ lower in the polluted soil when compared to the unpolluted soil. However, hydrocarbon utilizing bacteria and hydrocarbon utilizing fungi were $22 \%$ and $24 \%$ higher in the polluted soil than in the unpolluted soil respectively (Figure 2).

\section{DISCUSSION}

Generally, higher concentrations of these heavy metals 
Table 2. Maize and Cowpea growth performance on crude oil polluted and unpolluted soil.

\begin{tabular}{|c|c|c|c|c|c|c|c|c|c|c|c|c|}
\hline & \multicolumn{6}{|c|}{ Cowpea } & \multicolumn{6}{|c|}{ Maize } \\
\hline & $\begin{array}{l}\text { No of Leaf } \\
\text { Unpolluted } \\
\text { Soil }\end{array}$ & $\begin{array}{l}\text { No of Leaf } \\
\text { Polluted } \\
\text { soil }\end{array}$ & $\begin{array}{c}\text { t-test } \\
(\alpha=0.05)\end{array}$ & $\begin{array}{l}\text { Plant Height } \\
(\mathrm{cm}) \\
\text { Unpolluted } \\
\text { Soil }\end{array}$ & $\begin{array}{c}\text { Plant } \\
\text { Height } \\
(\mathrm{cm}) \\
\text { Polluted } \\
\text { soil }\end{array}$ & $\begin{array}{c}\text { t-test } \\
(\alpha=0.05)\end{array}$ & $\begin{array}{l}\text { No of Leaf } \\
\text { Unpolluted } \\
\text { Soil }\end{array}$ & $\begin{array}{l}\text { No of Leaf } \\
\text { Polluted soil ( }\end{array}$ & $\begin{array}{c}\text { t-test } \\
(\alpha=0.05)\end{array}$ & $\begin{array}{l}\text { Plant Height } \\
(\mathrm{cm}) \\
\text { Unpolluted } \\
\text { Soil }\end{array}$ & $\begin{array}{l}\text { Plant } \\
\text { Height } \\
(\mathrm{cm}) \\
\text { Polluted } \\
\text { soil }\end{array}$ & $\begin{array}{c}\text { t-test } \\
(\alpha=0.05)\end{array}$ \\
\hline Week 1 & 5 & 3 & $0.00002^{*}$ & 14.3 & 10.3 & $0.000001^{*}$ & 5 & 2 & $0.003^{*}$ & 23 & 12 & $0.0009^{*}$ \\
\hline Week 2 & 5 & 3 & $0.00002^{*}$ & 16 & 13 & $0.00018^{*}$ & 5 & 3 & $0.005^{*}$ & 33 & 15 & $0.00001^{*}$ \\
\hline Week 3 & 6 & 3 & $0.0005^{*}$ & 18.3 & 14 & $0.00003^{*}$ & 5 & 3 & $0.0003^{*}$ & 37 & 20 & $0.0002^{*}$ \\
\hline Week 4 & 11 & 5 & $0.0003^{*}$ & 23.3 & 18.3 & $0.00001^{*}$ & 6 & 3 & $0.0004^{*}$ & 44 & 24 & $0.0004^{*}$ \\
\hline
\end{tabular}

*Significantly different (t-test at $0.05 \%)$.

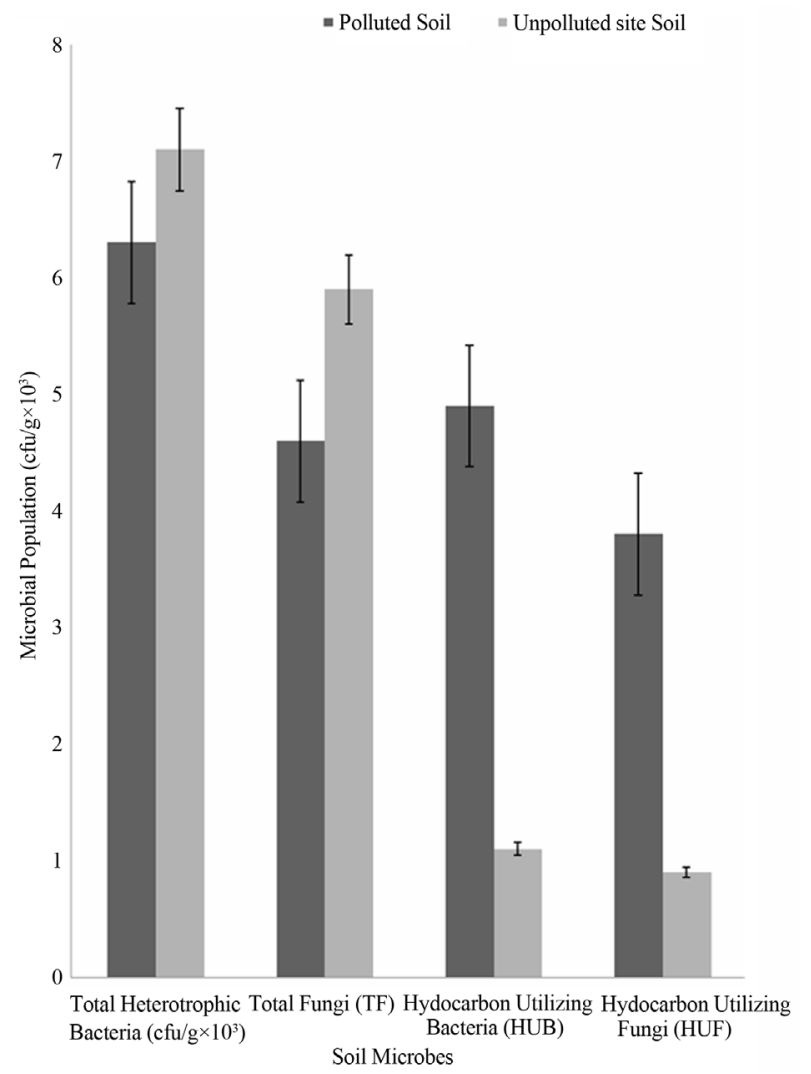

Figure 2. Microbial population of the polluted and unpolluted soil.

imposed by the crude oil pollution have negative effects on the vegetations. Heavy metals are potentially toxic and phytotoxicity for plants results in chlorosis, weak plant growth, yield depression, and may even be accompanied by reduced nutrient uptake, disorders in plant metabolism and reduced ability to fixate molecular nitrogen in leguminous plants [24].

The results of this reported higher concentrations of heavy metals in all the vegetations grown in crude oil polluted environment. Maize grown on polluted soil has the highest concentration of all the heavy metals. These results confirm that maize is a good hyperextractor which can be used in the process of phytoremediation of crude oil polluted site. Similarly, a high concentration of heavy metals was observed in polluted site vegetations than the unpolluted site vegetations. However, higher concentrations of these heavy metals imposed by the crude oil pollution have negative effects on the vegetations. Plants grown on crude oil polluted soil shows stunted growth. This is in agreement with the findings of Udo and Fayemi (1975) [28] who also found that the performance of maize plants after germination was seriously affected by oil pollution. Growth of tested crops was generally poor in the polluted soil and this agrees with the studies by Toogood and Rowell (1977) [29] and Odu (1981) [30] who reported retardation of growth at high levels of oil treatment. The reduction in growth could be attributed to a hindrance of transpiration and photosynthesis [31,32]. Heavy metals are potentially toxic and phytotoxicity for plants results in chlorosis, weak plant growth, yield depression, and may even be accompanied by reduced nutrient uptake, disorders in plant metabolism and reduced ability to fixate molecular nitrogen in leguminous plants [24].

Microbial analysis of the crude oil polluted and unpolluted soil revealed higher population of Hydrocarbon utilizing bacteria (HUB) in the crude oil polluted soil than unpolluted soil. Similarly, higher population of Hydrocarbon utilizing fungi (HUF) was recorded in crude oil polluted soil than unpolluted soil. This is as a result of the presence of hydrocarbon which serves as source of food for the HUB and HUF. This has favored the rapid replication of HUB and HUF thereby resulting to their high population in crude oil polluted soil. The lower microbial population of HUB and HUF observed in unpolluted soil was as a result of unfavorable condition imposed by lack of food. Total Heterotrophic Bacteria (THB) and Total Fungi (TF) are lower in crude oil polluted soil. This is as a result of adverse effect of the crude oil on the microbial population.

The difference in microbial population is also a reflec- 
tion of many factors such as nutrient and oxygen levels, temperature and availability of minerals [33]. The differences in both bacterial and fungal populations could then be attributed to possible change in nutrient and oxygen supply to the soils.

The growth performance of maize and cowpea grown on crude oil polluted soil was poor compared to unpolluted ones. Etiolating leaves were evident in both plant treatments which is a strong indication of nutritional deficiency imposed by crude oil pollution. Poor aeration of the soil which results in root stress might also be a factor. This is in agreement with the findings of [34] which states that root stress reduced leaf growth via stomata conductance.

\section{CONCLUSION AND RECOMMENDATION}

This study reported adverse effects of crude oil pollution on the growth of maize and cowpea as well as natural vegetation of the immediate environment. It can be concluded that crude oil pollution generally increases the heavy metal content of the soil on which it occurs. Hence plant grown on such polluted environment should not be eaten to prevent bio-accumulation of heavy metals in the population. However, the study shows that crude oil pollution encouraged rapid development of some hydrocarbon degrading microbes which utilize the crude oil as source of food thereby breaking down the hydrocarbon chain. Such microbes are useful in the process of bioremediation of crude oil polluted sites. Some microbes are however affected by the crude oil pollution thereby inhibiting their growth. This supports the work of (Chakrabarty, 1985) which states that bacteria species have different biodegradative capabilities. In addition, crude oil pollution was also observed to have a negative effect on the macro-fauna such as earthworms, beetles, larva etc. which plays a vital role in the ecosystem especially in the decomposition of dead organic matter.

\section{REFERENCES}

[1] Nelson-Smith, A. (1973) Oil pollution and marine ecology. Plenum Press, New York. http://dx.doi.org/10.1007/978-1-4757-6063-7

[2] Rowell, M.J. (1977) The effect of crude oil spills on soils: A review of literature. In: Toogood, J.A. Ed., The Reclamation of Agricultural Soils after Oil Spills. Part 1: Research, Alberta Institute of Pedology, Canada, 1-33.

[3] Agbogidi, O.M., Nweke, F.U. and Eshegbeyi, O.F. (2005) Effects of soil pollution by crude oil on seedling growth of Leucaena leucocephala (Lam.De Witt). Global Journal of Pure Applied Science, 11, 453-456.

[4] Institute of Pollution Studies, Rivers State University of Science and Technology (IPS, RSUT) (1986) Oshika Oil
Spill Environmental Impact Assessment, Nigeria.

[5] Nwanko, J.N. (1987) Critical analysis of oil spill incidents in Nigerian petroleum industry. Publication of $\mathrm{Ni}$ gerian National Petroleum Corporation (NNPC), 12.

[6] Department of Petroleum Resources (DPR). (1991, 1999) Environmental guidelines and standards for the petroleum industry in Nigeria. Ministry of Petroleum Resources, Lagos.

[7] Amadi, A., Abbey, S. D. and Nma, A. (1996) Chronic effects of oil spill on soil properties and micro flora of a rainforest ecosystem in Nigeria. Water, Air and Soil Pollution, 86, 1-11. http://dx.doi.org/10.1007/BF00279142

[8] Obire, O. (1988) Studies on the biodegradation potentials of some microorganisms isolated from water systems of two petroleum producing areas in Nigeria. Nigerian Journal of Botany, 1, 81-90.

[9] Baker, J.M. (1970) Studies on salt marsh communities. The effects of a single oil spillage. In: Colwell, E.B. Ed., The Ecological Effects of Oil Pollution on Littoral Communities, Institute of Petroleum, London, 16-43.

[10] Duffus, J.H. (2001) "Heavy metals” a meaningless term. Chemistry International, 23, 793-807.

[11] Anoliefo, G.O. and Vwioko, D.E. (1995) Effects of spent lubrication oil on the growth of Capsicum anum L. and Hycopersicon esculentum Miller. Environmental Pollution, 88, 361-364. http://dx.doi.org/10.1016/0269-7491(95)93451-5

[12] Hinojosa, M.B., Carreira, J.A., Ruız, R.G. and Dick, R.P. (2004) Soil moisture pre-treatment effects on enzyme activities as indicators of heavy metal contaminated and reclaimed soils. Soil Biology \&Biochemistry, 36, 15591568. http://dx.doi.org/10.1016/j.soilbio.2004.07.003

[13] Yao, H., Xu, J. and Huang C. (2003) Substrate utilization pattern, biomass and activity of microbial communities in a sequence of heavy metalpolluted paddy soils. Geoderma, 115, 139-148. http://dx.doi.org/10.1016/S0016-7061(03)00083-1

[14] Wang, Y.P., Shi, J.Y., Wang, H., Li, Q., Chen, X.C. and Chen, Y.X. (2007) The influence of soil heavy metals pollution on soil microbial biomass, enzyme activity, and community composition near copper smelters. Ecotoxicology and Environmental Safety, 67, 75-81. http://dx.doi.org/10.1016/j.ecoenv.2006.03.007

[15] United States Agency for International Development (USAID) (2010) Package of practices for maize production. Washington DC, 1-23.

[16] Oyewo, I.O. (2011) Technical Efficiency of Maize Production in Oyo State. Journal of Economics and International Finance, 3, 211-216.

[17] Agoda, S., Atanda, S., Usanga, O.E., Ikotun, I. and Isong, I.U. (2011). Post-harvest food losses reduction in maize production in Nigeria. African Journal of Agricultural Research, 6, 4833-4839.

[18] Singh, B.B., Ehlers, J.D., Sharma, B., Freire Filho, F.R. (2002) Recent progress in cowpea breeding. In: Fatokun, C.A., Tarawali, S.A., Singh, B.B., Kormawa, P.M. and Tamo, M. Eds., Proceedings, the World Cowpea Conference III, Challenges and opportunities for enhancing 
sustainable cowpea production, International Institute of Tropical Agriculture (IITA), Ibadan, 22-40.

[19] Langyinto, A.S., Loweberg-Deboer, J., Faye, M., Lambert, D., Ibro, G., Moussa, B., Kergna, A., Kushwaha, S., Musa, S. and Ntoukam, G. (2003) Cowpea supply and demand in west and central Africa. Field Crops Research, 82, 215-231. http://dx.doi.org/10.1016/S0378-4290(03)00039-X

[20] Valenzuela, H. and Smith, J. (2002) Cowpea: Cooperative extension service. College of Tropical Agriculture and Human Resources, University of Hawai at Manoa, Honolulu, 1-4.

[21] Singh, B.B. and Tarawali, S.A. (1997) Cowpea and its improvement: Key to sustainable mixed crop/livestock farming systems in West Africa. In: Renard, C. Ed., Crop Residues in Sustainable Mixed Crop/Livestock Farming Systems, CAB International, 322.

[22] Tarawali, S.A., Singh, B.B., Peters, M. and Blade, S.F. (1997) Cowpea haulms as fodder. In: Singh, B.B., Mohan Raj, D.R., Dashiell, K.E. and Jackai, L.E.N. (Eds). Advances in Cowpea Research. International Institute of Tropical Agriculture (IITA) and Japan International Research Center for Agricultural Sciences (JIRCAS), IITA, Ibadan, 375.

[23] Jordao, C.P., Nascentes, C.C., Cecon, P.R., Fontes, R.L.F. and Pereira, J.L. (2006) Heavy metal availability in soil amended with composted urban solid wastes. Environmental Monitoring and Assessment, 112, 309-326. http://dx.doi.org/10.1007/s10661-006-1072-y

[24] Guala, S.D., Vega, F.A. and Covelo, E.F. (2010) The dynamics of heavy metals in plant-soil interactions. Ecological Modelling, 221, 1148-1152. http://dx.doi.org/10.1016/j.ecolmodel.2010.01.003

[25] Sprynskyy, M., Kosobucki, P., Kowalkowski, T. and Buszewsk, B. (2007) Influence of clinoptilolite rock on chemical speciation of selected heavy metals in sewage sludge. Journal of Hazardous Materials, 149, 310-316. http://dx.doi.org/10.1016/j.jhazmat.2007.04.001

[26] Khan, S., Cao, Q., Zheng, Y.M., Huang, Y.Z. and Zhu, Y.G. (2008) Health risks of heavy metals in contaminated soils and food crops irrigated with wastewater in Beijing, China. Environmental Pollution, 152, 686-692. http://dx.doi.org/10.1016/j.envpol.2007.06.056

[27] Peer, J.R. and Rosen, W.G. (1977) Lead and Cadmium content of urban garden vegetable trace subst. Environmental Health, 11, 399-405.

[28] Udo, E.J. and Fayemi, A.A.A. (1975) The effect of oil pollution on germination, growth and nutrient uptake of corn. Journal of Environmental Quality, 4, 537-540. http://dx.doi.org/10.2134/jeq1975.0047242500040004002 $\underline{3 x}$

[29] Toogood, J. Am, Rowell, M.P. and Ngborg, M. (1977) Reclamation Experiment in the Reclamation of Agricultural Soils after Spills. Part 1: Research. In: Toogood, J.A. Ed, A. I. P. Publishers, Department of Soil Science, University of Alberta, Edmonton, 34-64.

[30] Odu, C.T.I. (1981) Degradation and weathering of crude oil under tropical conditions. Proceedings of the International Seminar on the petroleum industry and the Nigerian Environment, FMW\&H/NNPC, PTI Effurum, 143-154;

[31] Amakiri, J.O. and Onofeghara, F.A. (1983) Effect of crude oil pollution on the growth of Zea mays, Abelmoschus esculentus and Capsicum frutescens. Oil and Petrochemical Pollution, 13, 199-205. http://dx.doi.org/10.1016/S0143-7127(83)90182-5

[32] Udo, E.J. (1978) Thermodynamics of potassiumcalcium and magnesiumcalcium exchange reactions on kaolinitic soil clay. Soil Science Society of America Journal, 42, 556-560.

http://dx.doi.org/10.2136/sssaj1978.03615995004200040 $\underline{004 \mathrm{x}}$

[33] Harris, E. (1962) Diseases of Guinea corn. Samaru Technical Notes, Volume II. Institute of Agricultural Research Zaria.

[34] Smith, B., Stachowisk, M. and Volkenburgh, E. (1989) Cellular processes limiting leaf growth in plants under hypoxic root stress. Journal of Experimental Botany, 40, 89-94. http://dx.doi.org/10.1093/jxb/40.1.89 